\title{
The $\mathrm{Ka}$ - Passive Form in Balinese
}

\author{
Nyoman Sujaya \\ Warmadewa University, Bali, Indonesia \\ Ketut Artawa \\ Udayana University, Bali, Indonesia \\ I Nyoman Kardana \\ Warmadewa University, Bali, Indonesia \\ Made Sri Satyawati \\ Udayana University, Bali, Indonesia
}

\begin{abstract}
This paper accounts for the $k a$ - passive form in Balinese. It focuses on its syntactic and semantic representation. Using the data taken from Balinese narrative texts issued in the Bali Orti of Bali Post newspaper, and applying the RRG theory by Van Valin and Randy (1999), it was found out that the $k a$ passive belongs to a morphological passive voice of Balinese where the the voice is marked on the verb (it is marked by prefix $k a$-). The $k a$ - base form can be attached by applicative suffixes such as -ang, -in, and -an. These morphological verbs imply various syntactic structure and semantic representation.
\end{abstract}

Index Terms-prefix $\mathrm{ka}$-, passive, syntactic and semantic analysis

\section{INTRODUCTION}

Balinese is one of the larger regional languages in the middle part of Indonesia. This language is spoken by around $3,247,283$ speakers, about $77 \%$ of the population of Bali, which was recorded as 4.2 million. Balinese language is mainly spoken by Balinese people living in Bali and those living in other parts of Indonesia, like Lombok, and Sulawesi.

Although Balinese is widely used in social interaction, especially in custom and cultural interaction, in practice the native speakers of Balinese often made errors in using their own language. This is possibly due to the influence of Indonesian, the national language, and the English language which nowadays is widely used in Bali for tourism businesses. This phenomenon possibly makes young Balinese more interested in using Indonesian and English rather than Balinese so that they are not fluent enough in using their own language, Balinese. In their daily life some Balinese are not good in using suffix -ang and -in. They used them interchangeably. They often say enjuh-in tambahe 'hand over the hoe for 'enjuh-ang tambahe 'hand over the hoe'. It is like the error of using suffix $-i$ and -kan in Indonesian. It is wrong to say Dia menyuguh-kan tamu itu dengan kue 'She offered cakes to the guest'. The correct one is that the verb suguh 'offer' should be in the derivational form with suffix $-i$ if it is directly followed by an animate object.

Seeing the condition that the use of Balinese by young Balinese is decreasing, the government of Bali made an effort to preserve it through offering Balinese subject in the curriculum of the elementary, junior and senior high schools. The government also offered Balinese day on Wednesdays for every institution in Bali. In this case everybody is obliged to use Balinese when they communicate with each other. Not only that, the Balinese government also put Balinese teachers at every school in the countryside as the extension agent.

In recent years, a number of linguists have done researches on syntax of Austronesian languages, including Balinese. Artawa (2013) wrote about the basic verb constructions of Balinese. In his study it was stated that Balinese has a number of peculiar properties. It has passive like properties in which the patient is the subject but the verb is unmarked. There is also a split of the third pronominal Agent in Low Balinese represented as an enclitic $-a$ on the verb followed by an Agent adjunct represented by a prepositional phrase. Indrawati (2011) examined about Balinese serial verbs construction and found out that the Balinese serial verb constructions express a single macro-event that can be classified into two types: component SVC and narrative SVC. Syntactically, SVCs in Balinese are biclausal constructions, some are monoclausal, and some are successive clausal. Arka (1998) made a research on speech levels, social predicates and pragmatic structure in Balinese and found out that social information be treated in terms of social predicates and modeled using LFG-style parallel structures. The social predicates are contained in what is called pragmatic- structure (prag-str). It is demonstrated that this approach can account for the plain as well as the (dis) honouring use of linguistic forms in Balinese. Other works on Balinese related to grammar have also been discussed by some linguists like Kersten (1984) and Oka Grandoka et al. (1985). Another researcher, Suryati (1997) with the topic Balinese verbs that have complementation in Balinese, is about grammatical analysis on Balinese verbs. However, they have not discussed how the morphosyntax works on passive voice in Balinese that has several forms and implies various different constructions and meanings. They have not analyzed it in detail seen from syntactic and semantic viewpoint. 
The focus of this study is on the syntactic and semantic analysis of the $k a$-passive form in Balinese. The analysis was supported by data in the form of narrative text taken from Bali Orti pages of the Bali Post newspaper issued in the year 2017, 2018, and 2019. The text contains some different kinds of articles that generally use low and high Balinese. In this study, the notion of Patient and Agent as the macroroles which was quoted from Van Valin and Randy (1999) were used for the analysis.

The structure of this paper is organized as the following sections. Section one is about the introduction. In this case it is explained why this topic is necessary to discuss. Not only because of theoretical reason but also because of practical reason. In two, there will be about the related study. In this section it is explained about the Balinese noun phrase construction, verb morphology, basic verbs, and derived verbs. This is necessary to do since the analysis is mainly done through analyzing the morphosyntax phenomenon. In section three there will be the discussion of $k a$ - constructions with its semantic and pragmatic representation. It will be clearly explained how the morphosyntax works for the passive using the $\mathrm{ka}$ - forms. And for the last section, it will be about the conclusion of this study.

\section{THEORETICAL FRAMEWORK}

This research uses the RRG theory proposed by Van Valin and Randy (1999). This theory states that language is a system of communicative social action, and that's why analyzing the communicative function of grammatical structures plays important role in grammatical description. RRG not only concerns with syntactic structure but also with semantic and pragmatic relations. However, since this is about the syntactic and semantic analysis of Balinese prefix, in this section it is necessary to explain about Balinese syntax and morphology, including the noun phrase and Balinese derivational morphology.

\section{A. Noun Phrase Structure}

According to Artawa, in Balinese, like in other languages, a noun phrase (NP) consists of a noun (as the head) and usually followed by a modifier (Artawa, 2013).

Examples:

Cicingé gedé

Jelema lengeh

When a noun phrase is definite, the noun head is marked by $-e ́$ and this definite noun phrase is usually used together with demonstrative pronouns ené 'this' or ento 'that'. Examples:

Definite noun phrase without demonstrative pronouns show ambiguity.

$$
\begin{aligned}
& \text { Cicingé gedé } \\
& \text { Deg-DEF big }
\end{aligned}
$$

The example above may mean 'the big dog' or 'the dog is big'

Balinese noun phrase, like the examples above, can also occur with relativiser ané/sané.

Examples:

Cicing-é ané gedé ento

Dog-DEF which big that

'The big dog'

A modifier expressing an inherent property of its referent in a definite noun phrase is marked by $-e$ attached to the modifier.

Examples:

Motor vespan-é

Motor vespa-DEF

'The vespa motor'

A noun head can also be modified by a clause, which is usually introduced by the relativiser ané/sane.

Examples:

Motor ané tegak-in cai ento maal.

Motor DET ride-APPL $2^{\text {nd }}$ that expensive

'The bike that you ride is expensive'

A definite noun phrase can also be in the possessive construction. In this construction it is usually the possessor which is marked.

Examples:

Motor cai-né

Motor $2^{\text {nd }}-$ POSS

'your motor bike'

However, if the possessor is a third person noun or pronoun, possession can be marked either on possessor or possessee.

Examples:

Motor Nyoman-é 'Nyoman's motorbike'

Motor-né Nyoman 'Nomam's motorbike' 


\section{B. Balinese Derivational Morphology}

Balinese, like many other languages in Indonesia, has basic and derived verbs (Warna, 1983). Beside these two kinds of verb construction, there is also the existence of what Artawa calls 'precategorial' roots (Artawa, 1994), a lexical form which will only have verbal lexical function if it is attached with prefix or suffix. Take the form enjuh 'give' as an example. In order that this form can function syntactically, this root should be attached with prefix $N$ - and/or suffix -in or -ang like in the following examples.

*Icang enjuh ia tambah

1SG hand 3SG hoe.

'I handed him a hoe'

Icang N-enjuh-in ia tambah

1SG N-hand-APPL 1SG hoe

'I handed him a hoe'

\section{Basic Verb and Derived Verbs}

Basic verb, called keruna lingga in Balinese, is a base form with no affixation and reduplication. The basic verb can be classified into transitive or ditransitive.

$$
\begin{aligned}
& \text { Céléng-é adep tyang } \\
& \text { Pig-DEF sell 1SG } \\
& \text { 'I sold the pig' } \\
& \text { Pipis-é baang tyang iya } \\
& \text { Money-DEF give 1SG 3SG } \\
& \text { 'I gave him the money' }
\end{aligned}
$$

A derived verb is a verb formed through the attachment of affixes. The forms like dagang 'seller', adep 'sell', dan jéjér 'in line' belong to basic forms. Now let us see the derived ones.

$$
\begin{array}{llc}
\text { Dagang-é } & \multicolumn{2}{c}{\text { ma-dagang dagang-an }} \\
\text { Dagang-é } & \text { ma-dagang } & \text { dagang-an } \\
\text { Seller-DEF } & \text { VBL-seller } & \text { seller-NOM } \\
\text { 'the seller } & \text { 'to sell' } & \text { 'things sold' }
\end{array}
$$

We can see here that the word dagang-é comes from dagang plus suffix -é, ma-dagang from dagang plus suffix ma-, and dagang-an comes from dagang plus suffix -an.

Balinese has prefix $N$-, $m a-, k a-, p a-, p i-, s a-, a-, p r a, p a r i-, p a t i-, m a k a-$, saka-, kuma-. Balinese suffixes are; - $a$, ang, -in, -an, -é, -né, -n, -ing. Those belonging to confix are; $p a-a n, m a-a n, k a-a n$, and bra-an. Balinese infixes are; -um-, -in-, -el-, -er-. The four kinds of affix in Balinese can be attached to noun, adjective, adverb, or verb to form derivation forms and express various meanings.

In Balinese, the morphological distinct kinds of prefixes and suffixes bring not only different functions but also syntactic alternations and semantic representation. Prefix $m a$-, for example, is never followed by an object. Let's have a look the following examples.
*Ia ma-gaé banten
1SG work offering
'She made offering'.
Ia N-gaé banten
1SG make offering.
'She made offering'

In Balinese derived verb constructions, the verb can be transitive or intransitive. A transitive can be mono transitive or ditransitive (verb with three arguments). Free base verbs and bound verbs can become the verb of three arguments through morphological processes (such as the suffixation of an applicative).
Consider the following examples.
Mén Sulastri ma-gaé
Mother Sulastri work
'Mother Sulastri works'
Mén Sulastri $N$-gaé baju
Mother Sulastri make shirt
'Mother Sulastri made a shirt'
Mén Sulastri N-gaé-ang panak-né baju
Mother Sulastri work-APPL child-POSS shirt
'Mother Sulastri made her child a shirt'

\section{Balinese Passive Verbs}

As stated previously, ma- form can be used to express passive sentence in Balinese. In fact, Balinese passive sentences can be realized by various constructions among those there is the $\mathrm{ka}$-form. Generally, when the verb is in $\mathrm{ka}$ form (-ang or -in) the agent is expressed with the PP. This form expresses passive voice. This will be further discussed 
in section three.

1. Basic form

As stated by Kersten (1984), Balinese basic verb construction can be one type of passive sentence. It was also stated that the agent can be first, second, or third person pronoun. As stated by Artawa (2013), traditionally passive constructions have patient subject. The general word-order of the basic form denoting passive is Patient $+\mathrm{Vp}(\mathrm{base})+$ Agent (Recipient).

Kadén melahan tunas surudan-né anggon iraga padidi (Bali Post, 27/8/2017)

Indeed better take offering-DEF for us alone

'Indeed it is better to take the offering for ourselves'

Di Bali kadirasa makejang dadi adep (Bali Post, 7/1/2018)

2. Suffix $-a$
In Bali seem all can sell
'In Bali it seems everything can be sold'

The subject of verbs with - $a$ may be any of the three person, but the suffix shows that the agent is in the third person, though the context may not tell who he is. The meaning of the suffix is thus that an event occurs, originated by someone other than the subject. This indication which is often not expressed in English, but taken for granted, is significant for the Balinese: usak 'in damage condition' usaka 'it has been damaged by someone or something'

Though in theory the suffix - $a$ refers to a definite, known agent, in many instances this does not mean that someone acted, rather an event is being described. In this case the $-a$ becomes merely an ending indicating the passive voice of the verb.

If the speaker prefers to express the agent with a preposition, he uses $\mathrm{L}$ tekén or baan, $\mathrm{H}$ ring, or antuk and the phrases follow the verb, though not necessarily immediately.

Examples:

Nasin-é bang-a pianak-né baan I mémé

Rice-DEF give-PASS child-POSS by mother

'The cooked rice is given to the children by mother'.

Ia lakar ngempug waluh ané bang-a ngidih tekén

$3^{\text {rd }}$ will open pumpkin that give-PASS give by

I Dadong Rangsasané (Bali Post, 25/2/2018)

I Dadong Rangsasa

3. $M a$ - form

'She will open the pumpkin that was given by I Dadong Rangsasa'

In Balinese there are some forms with $m a$ - base that express the subject that does not play the role as agent, but rather a patient. In this case, although they have passive interpretation, they are considered transitive. This form is used when it is considered that the agent is not important (Joseph, in Hunter: 1988). In this case the ma- stative has passive meaning. It refers to patient argument rather than agent.

Examples:

Bé-né suba ma-goréng

Fish-DEF already sta-fry

'The fish has been fried'

Sampi-né jani ma-tegul

Caw-DEF now sta-tie

'The caw now is tied'

\section{RESEARCH METHOD}

This paper applies a descriptive qualitative method using Balinese narrative texts in the form of articles occurring in the Bali Orti, special pages of the Bali Post newspapers issued on Sundays. The data were randomly taken from the last three years (2017 - 2019) copies so that there were about 576 pages. The texts were in the form of articles with Low or High Balinese register. Informants (some of them are Balinese teachers) were also used to support the data.

The analysis was done through applying the RRG conception, that was analyzing the grammatical structure with reference to semantic and communicative functions. The analysis was to show how the morphosyntax works on the constructions of the $k a$ - form. It was tried to see the arguments involved in the $k a$-forms so that we could see the word order assigned by the $k a$ - forms. By applying this method and using the macrorole theory of Van Valin and Randy (1999), we could have syntactic and semantic properties of the $k a$ - form.

\section{Result AND Discussion}

It is true that in passive sentences the patient is the main orientation, the agent is not the focus or not being considered. In Balinese, the $k a$ - passive forms show the morphosyntactic variation and they carry a number of different meanings. In relation to this study, it was found out that there were five types of $k a$ - passive form; $k a$ - base form, $k a$ - 
base - ang form, $k a$ - base -in form, and $k a$ - base -an form. In $k a$ - passive form, the agent, if mentioned, is marked by preposition teken, baan (low register), and antuk, or ring (high register) 'by'.

A. Ka- + Base Construction

In this construction the $k a$ - only modifies the transitive verbs. It means that it cannot be attached to other verbal bases like an adjective, adverb or intransitive verb except it is followed by suffixes (-an, -ang, or -in). This type of construction is used to express a non-volitional activity. It can also be used to express the meaning of 'in the condition of'.

Examples:

I pianak patut taler ka-icén paplajahan sané anut (Bali Post, 27/8/2017)

DET child appropriate also given knowledge that good

'Our children are appropriate to be given good knowledge'

Ipun stata ka-pracaya nabuhang rindik rikala ngayah

3SG always PASS-trust play rindik when serve

wiadin pentas (Bali Post, 3/2/2019)

or perform

'He is always trusted to play rindik when serving or perform'

Dané ketah ka-panggih ngatur-ang ayah (Bali Post, 7/1/2018)

3SG/PL often PASS-find give-APPL service

'They are often found to do social work'

The ka- base form is often used with no agent. $\mathrm{Ka}$ - base constructions with no expression of agent may have the construction of $\mathrm{V}-\mathrm{P}$.

Examples:

Ka-cerita Ni Ubuh sedekan maan ngidih padi (Bali Post, 3/2/2019)

PASS-tell Ni Ubuh ASP get have paddy

It was told Ni Ubuh had got paddy'

Nénten ka-rasa yéning mangkin galahé sampun wengi (Bali Post, 4/3/2018)

Not PASS-feel if now time already evening

'We do not realize that it is going to be dark'

Ka-rereh dewasa Karna Sula sané majanten kapanggihin pangrauh-ipun

PASS-find good time Karna Sula that certain found coming-its

nyabran sasih (Bali Post, 10/9/2017)

every month

'It is tried to find a good day of Karna Sula that really comes every month'

Lantas ka-tegul bungut kuluk-é

Then PASS-tie mouth dog-POSS

'Then the dog's mouth was tied'

If there is an agent, they may be in the first person, second person or third person. However, this type is very limited. Examples:

Ka-manah antuk tittiang

PASS-think by 1 SG

'understood by me'

Yan sampun pagentosan, sinah ka-panggih antuk bapa.

If ASP change sure PASS-find by me

'If it were for me, I would find it'

Anget ka-rasa antuk ida angkihan Ni Serimpen.

Hot PASS-feel by 3SG breath NI Serimpen

He felt Ni Serimpen's breath was hot'

The agent that is strongly used in the $k a$ - base form is the preposition baan 'by' with the construction $\mathrm{V}-$ baan $-\mathrm{A}$ (pro) $-\mathrm{O}$

Example:

Sawireh tan ka-pineh baan kai unduké nto

Because not PASS-think by $1 \mathrm{SG}$ problem that

'Because I did not understand the problem'

This type is usually replaced by the type of passive using the base form.

Examples:

Katulak antuk titiang $\rightarrow$ tulak titiang 'I refused it'

Kapanggih antuk bapa $\rightarrow$ panggih bapa 'I found it'

The agent in the first clause can also be the agent in the second clause.

Example:

Méga motong tumpeng ulang tahun-é ka-atur ring Gusti Ngurah Jelada (Bali Post, 4/2/2018) 
Méga cut rice birthday-DEF given to Gusti Ngurah Jelada

'Méga cut the birthday rice and it was given to Gusti Ngurah Jelada'

\section{B. Ka- Base -ang}

The $k a$ - base -ang constructions, considered as the Second Passive by Kersten (1984), express patient reference. In this construction the base can be filled by adjective, noun, adverb, intransitive verb, and transitive verb. These constructions express various meanings.

1. Ka- -ang Modifying Adjective

When $k a$ - -ang modifies an adjective base, the resulting derived transitive has or express the meaning of 'making something in the condition denoted by the base'. The logical structure, as defined by Van Valin \& Randy, is "BECOAME predicate' (x)". In this case $\mathrm{x}$ represents the underlying adjectival base.

Examples:

Akéh pisan madué pepunded sané ka-tami-ang saha

Many very have object that PASS-inherit-APPL and

ka-tenget-ang olih karma-né irika (Bali Post, 16/12/2018)

PASS-haunted-APPL by people-DEF there

'There were many sacred objects that were inherited and haunted by the people there'

Tembok-é sampun ka-tegeh-ang tiang

Wall-DEF already PASS-tall-APPL 1 SG

'I have made the wall high'

2. Ka- -ang Modifying Noun

The $k a$ - -ang modifying a nominal base forms a transitive verb that has the logical structure of an accomplishment verb of passive form "BECOAME predicate' (x)". In this case $\mathrm{x}$ represents the underlying nominal base.

Examples:

Ida sane ka-plebon-ang p punika prasida gelis mamargi becik (Bali Post, 16/12/2018)

He that PASS-cremate-APPL that can soon go good

'He who is being cremated will soon run well'

Sinah nyanan ka-margi-ang antuk tatujon (Bali Post, 20/1/2019)

Seen next PASS-go-APPL by purpose

3. Ka- -ang Modifying Adverb

'We can see it will be done in accordance with expectation'

There is also a directional aspect with -ang in the passive form with $k a-$. This is used to indicate the performance of an intransitive action related to the base (for instance with compass points).

Examples:

Ka-tengah-ang ngejang gelas-é!

PASS-center-APPL put glass-DEF

'Move the glass to the middle'

4. Ka- -ang Modifying Intransitive verb

This construction also expresses the meaning of making something do the action denoted by the verbal base represented in the construction.

Examples:

Napi-ké sampun sami senjatané ka-medal-ang (Bali Post, 18/2/2018)

What-? already all weapons PASS-out-APPL

'Have all the weapons been taken out?'

Tumpang-tumpangan-ipun ka-adung-ang malih (Bali Post, 16/12/2018)

stages-POSS PASS-match-APPL again

'The stages were again readjusted'

Prabéané makasami ka-medal-ang antuk désa

Cost-DEF all PASS-take out-APPL by village

'All the cost was paid by the village'

5. Ka- -ang Modifying Transitive verb

-ang in this construction refers to changes of state or transferable states meaning that the action is volitional and the agents are animate. It may express benefactive or causative meaning.

Examples:

Sekancan sané ka-dué-nang taler kaicén jotan (Bali Post, 27/8/2017)

Everything that ka-own-APPL also given offering

'Whatever they own were also offered with offering'

Ka-beli-ang tiang panak tiang-é sepeda

PASS-buy-APPL 1SG child 1SG-POSS bicycle

'I bought my son a bicycle' 


\section{Ka-Base-in}

Like $k a$ - base - ang, the $k a$ - base -in constructions quite frequently have an agent, normally expressed by preposition L tekén, baan 'by', $\mathrm{H}$ antuk 'by'. But occasionally these verbs are followed by an unmarked noun agent. So the construction will be: $\mathrm{P}-\mathrm{V}-$ (prep) A

Examples:

Keben-é ka-penpen-in baas baan I Kadék

Basket-DEF ka-fill-APPL rice by I Kadék

'The basket was filled with rice by I Kadék'

Ada bambang linggah bek ka-pacek-in tumbak

There hole wide many ka-pierce-APPL spear

'There was a hole that was full of spears'

In example above we can see that the agent I Kadék is marked with preposition baan 'by', while in the second sentence it is not.

If the agent is the first person or second person, it is suggested to use the base-in form which applies the agent postverbally.

Examples:

Penpen-in tiang 'I fill'

Penpen-in cai 'You fill'

The word class of the base in this construction may be an adjective, a noun, or a verb. They express various meanings (depending on the lexical base).

1. Ka- -in modifying an adjective.

This construction expresses the meaning of 'become more'

Example:

Ka-tegeh-in témboktiangé apang kéweh malingé macelep

Pass-high-APPL wall 1SG-POSS in order difficult thief-DEF come in

I made my wall higher in order that the thieves will difficult to go inside'.

2. Ka- -in Modifying Nominal Base

This construction expresses the meaning of 'wearing' or 'using'

Example:

Tan ka-udeng-in panak tiang-é sawiréh ia kari cenik pisan.

Not Pass-udeng-APPL 1SG-POSS because 3SG small very

'I did not wear him udeng because he is still very young'

3. Ka- -in Modifying Verb Base

This construction may imply a number of different meanings.

a. -in Implying Goal Applicative

Palinggih sané majanten ka-panggih-in marupa Padma (Bali Post, 27/8/2017)

Palinggih that certain PASS-find-APPL in the form Padma

'Pelinggih that will be definitely found is Padma'

b. -in Implying Recipient Applicative

Penari-né ka-atur-in wédang lan sanganan (Bali Post, 7/1/2018)

Dancer-DEF ka-give-APPL coffee and cakes

The dancers were given coffee and cakes'.

c. -in Implying Instrument Applicative

Botol lengis-é ka-sengseng-in tiang baan sambuk

Bottle oil-DEF PASS-clog-APPL 1SG with coconut fiber

'I clogged the bottle of the oil with coconut fiber'

\section{Ka-Base-an}

Normally $k a$ - forms without suffix and $k a$ - form with suffix -an do not have an agent. In the $K a$ - base -an constructions the agent is completely suppressed. These forms express two kinds of different meanings. First, it expresses an accidental passive, and second it expresses abstrumental passive.

The examples of accidental passive:

Ada koné anak luh daa, ubuh uli cenik ka-tinggal-an

There told child girl young orphan since young ka-leave-APPL

rerama luh muani (Bali Post, 3/2/2019)

parents female male

'It was told that there was a young girl who became an orphan since she was very young'

Pradé di malipetané Cening lantas ka-tengah-an, uber-a

If at return-DEF 2SG then PASS-middle-APPL run after-3SG

Cening tekén rangsasané. (Bali Post, 16/12/2018) 
2SG by giant-DEF

'When in your return then you go deeper, you will be chased by the giant'

Sukat ia ngabajimat tusing taén ka-ilang-an pipis

Since 3SG bring talisman not ever ka-lose-APPL money

'Since he brought the talisman he never lost his money'

In some cases, this construction, according to belongs to the type of abstrumental passive, it is a locative-like of -an, the agent is not thought about. And the construction is $\mathrm{P}-\mathrm{V}-\mathrm{NP} / \mathrm{abstrument}$. However, the usage of this form is very limited. Let us see the following examples.
Carikné ka-pegat-an
Rice paddy-pro3 PASS-cut off-APPL water
'His rice field got its water cut off'"
Rauh irika Ida ka-atur-an rayunan
Arrive there 3SG PASS-offer-APPL food
'Arriving there he was offered food'

If there an agent in this construction, the agent is considered in common or unmarked, not definite or certain person or thing.

Examples:

Karauhan tamu 'visited by guests'

Karangsukan babai 'filled by the magic power'

Katimpan rejeki 'got sustenance'

Katinggalan mémé bapa 'left by parents'

Katiban rejeki 'got sustenance'

The verbs kélangan which is in low register with ilang as its base and Kécalan which is in high register with ical as its base belong to the $k a$ - base -an passive forms. These verbs are sometimes uncontracted: kailangan, kaicalan. The meaning of these verbs are 'be lost', 'vanish', or 'disappear'. In the construction of these verbs, the subject of the passive verb is not the thing lost but the person who lost something. Kélangan and kécalan means 'be lost from something'.

Examples:
Anaké
cenik ento $k$-élang-an
Child-DEF small that Pass-lose-APPL mother father
'The little kid lost his parents'
Gusti Ngurah k-écal-an bungkung asiki
Gusti Ngurah PASS-APPL ring one
'Gusti Ngurah lost one ring'

mémé bapa

\section{CONCLUSION}

This paper has discussed syntactic and semantic analysis of $k a$-passive form. How the morphosyntax works in this construction has also been introduced. The use of the $k a$ - passive form, as one of the passive forms in Balinese, has also been described. However, there are constraints in terms of sociolinguistic factors in choice of the $k a$-passive types.

Syntactically, the $k a$ - passive forms imply participant marking morphology, and they have important functions in the organization of discourse, especially when used with -ang and -in applicatively. It is important to note that the $k a$ - basic (suffix) derivations are used in all register to indicate reference to patient argument where the action is seen as nonvolitional activity, it is like experiencer role. $K a$ - basic (suffix) sentences are typically found in $\mathrm{P}-\mathrm{V}-(\mathrm{A}), \mathrm{V}-\mathrm{P}-(\mathrm{A})$, or $\mathrm{V}-\mathrm{A}-\mathrm{P}$ form. The difference between the $k a$-form with suffix -ang and -in is that when there is the meaning of dynamicity of the patient, or when the construction is used to express the mobile object, the -ang form is chosen. -in form is chosen when the subject of the passive clauses is as source.

\section{ACKNOWLEDGEMENTS}

I would like to thank Jro Mangku Alit (the priest of Balinese family temple), Nyoman Juana (the head of Abian Kapas traditional village), Dewa Putu Sumantra (the expert of Balinese and Indonesian language), Ketut Subagia (a linguist), and other Balinese friends for being informants in relation to this study.

\section{REFERENCES}

[1] Arka, I Wayan. (1998). From Morphosyntax to Pragmatics in Balinese: A Lexical Functional Grammar. Sydney: University of Sydney.

[2] Artawa, Ketut. (1994). Ergativity and Balinese Syntax. Australia: La Trobe University.

[3] Artawa, Ketut. (2013). The Basic Verb Construction in Balinese. Jakarta: NUSA Vol. 54. The Center for Language and Culture Studies Atma Jaya University. 
[4] Hunter, Thomas Marshall. (1988). Balinese Language: Historical background and contemporary state. USA: The University of Michigan.

[5] Indrawati, Ni Luh Ketut Mas. (2011). Konstruksi Verba Beeruntun Bahasa Bali (Kajian Semantik dan Sintaksis). Denpasar: Program Pascasarjana Universitas Udayana.

[6] Suryati, Ni Made. (1997). Verba Berkomplemen dalam Bahasa Bali. Bandung: Program Pascasarjana Universitas Padjajaran.

[7] Unnamed. (27/8/2017). Bali Orti. Bali Post.

[8] Unnamed. (10/9/2017). Bali Orti. Bali Post.

[9] Unnamed. (7/1/2018). Bali Orti. Bali Post.

[10] Unnamed. (4/2/2018). Bali Orti. Bali Post.

[11] Unnamed. (18/2/2018). Bali Orti. Bali Post.

[12] Unnamed. (25/2/2018). Bali Orti. Bali Post.

[13] Unnamed. (4/3/2018). Bali Orti. Bali Post.

[14] Unnamed. (16/12/2018). Bali Orti. Bali Post.

[15] Unnamed. (20/1/2019). Bali Orti. Bali Post.

[16] Unnamed. (3/2/2019). Bali Orti. Bali Post.

[17] Warna, I Wayan, et. al. (1983). Tata Bahasa Bali. Denpasar: Pemerintah Daerah Provinsi Daerah Tingkat I Bali

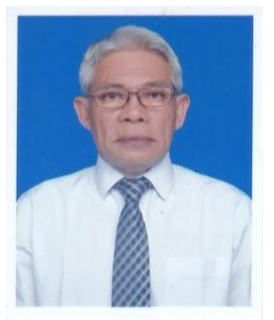

Nyoman Sujaya, was born in Singaraja, Bali, Indonesia. He is one of the lecturers at the English Department, Faculty of Letters, Warmadewa University, Bali, Indonesia. He obtained his master degree in linguistics from Udayana University, Bali, Indonesia in 2003. He is currently a doctorate candidate in linguistics majoring on syntax at Udayana University and his main research focusses on Balinese "Giving" Verb Constructions.

Ketut Artawa is a professor in Linguistics at Udayana University, Bali, Indonesia. He received his Master Degree in Linguistics from La Trobe University in 1992 and got his Doctorate also from La Trobe University in 1995. His research interest involves a wide range of topics about syntax and he has supervised many theses and doctorate dissertations. Up till now he has written a lot of books and articles and has participated in a number of national and international seminars and conferences.

I Nyoman Kardana is a professor in Linguistics at Warmadewa University, Bali Indonesia. He got his Master Degree in Linguistics from Padjadjaran University, Bandung, Indonesia in 1998. He obtained his Doctorate Degree in Linguistics from Udayana University, Bali, Indonesia in 2004. His research interest involves a lot of topics about syntax and semantics and he has supervised many papers, theses and doctorate dissertations. He has also written a lot of articles and books and has participated in a number of national and international seminars.

Made Sri Satyawati is a lecturer at Udayana University, Bali, Indonesia. She obtained her Master Degree in Linguistics from Padjadjaran University, Bandung, Indonesia in 1999 and she got her Doctorate Degree in Linguistics from Udayana University in 2010. Her research interest is linguistics, namely syntax and semantics. Her publications involve study on local languages in Indonesia. She has supervised many theses and doctorate dissertations and has participated in a number of national and international seminars. 